\title{
Proceeding
}

Supplementary Issue: Winter Conferences of Sports Science. Costa Blanca Sports Science Events, 25-26 January 2019.

Alicante, Spain

\section{Pilot case study on rhythmic gymnastics and dyslexia}

\author{
BARBARA SENATORE ${ }^{1} \triangle$, MANUELA VALENTINI $^{2}$, ARIO FEDERICI ${ }^{2}$, FRANCESCA D'ELIA ${ }^{1}$ \\ 1 University of Salerno, Italy \\ 2University of Carlo Bo Urbino, Italy
}

\begin{abstract}
Rhythmic gymnastics is an Olympic sport with qualifying and coordinating features characterized by "small tools". The competitive program includes both individual and team performances. An individualist gymnast presents four different routines, each with a different tool, while the team presents two different compositions, one with the same type of tool and the other with two types of tools. Dyslexia is a learning disorder, the failure of the development of hemispheric dominance or conflicts of dominance between the two hemispheres. In addition to having learning problems, people suffering from dyslexia also have problems in cognition of their bodies within space and with the musical rhythm. The aim is to analyse a case of dyslexic athlete inherent to performance, self-esteem and sociality. Through the case study and ethnographic approach it was found that the gymnast manages to achieve the same results as the other gymnasts who train with her, but showing a small difficulty in teamwork. These results encourage to explore the links between activities and data because you have in front of you an athlete to all intents and purposes, with every pros and cons that every human being can show, even if in this case the corrections must be made in a more patient way and for the results you have to wait a little more time. Key words: Rhythmic gymnastics; Dyslexia; Assessment.
\end{abstract}

\section{Cite this article as:}

Senatore, B., Valentini, M., Federici, A., \& D'Elia, F. (2019). Pilot case study on rhythmic gymnastics and dyslexia. Journal of Human Sport and Exercise, 14(2proc), S198-S205. doi:https://doi.org/10.14198//hse.2019.14.Proc2.06

Corresponding author. University of Salerno, Italy.

E-mail: senatorebarbara@gmail.com

Supplementary Issue: Winter Conferences of Sports Science. Costa Blanca Sports Science Events, 25-26 January 2019. Alicante, Spain.

JOURNAL OF HUMAN SPORT \& EXERCISE ISSN 1988-5202

(c) Faculty of Education. University of Alicante.

doi:10.14198/jhse.2019.14.Proc2.06

S198 | 2019| Proc2 | VOLUME 14

C 2019 University of Alicante 


\section{INTRODUCTION}

Rhythmic gymnastics is a technical-composite sport characterized by the "small tools" that are: rope, hoop, ball, clubs and ribbon.

On individual programme, the competition includes the use of four of the five equipment used in this sport and, in turn, one of them is left out: for example, during this four-year Olympic period, the rope was kept out.

The technical and choreographic compositions of the individual gymnasts are performed on music ranging from 1.15 to 1.30 minutes and the gymnast must perform jumps, rotations and balances as well as risks, and then continue with masteries and finally dance steps.

To the team championship, five gymnasts take to the platform, who, together, make movements in synchrony as if they were a single gymnast. They must perform jumps, rotations and balances, risks, collaborations, tool exchanges and dance steps. Another characteristic of the team composition is that the gymnasts, besides performing the exercises on a music that can go from 2.15 to 2.30 minutes, presents a routine of two exercises and these routines can be: one with all the same tools and one in which the tools are mixed (for example two ribbons and three balls, two circles and three pairs of clubs, etc.).

The bible of each rhythmic gymnastics technician is the score code (CdP) and competitions are held on a platform 13x13 meters. (Federazione Ginnastica D'Italia).

Dyslexia is essentially the failure development of hemispheric dominance or conflicts of dominance between the two hemispheres (De Grandis, 2007.), but it is reductive to translate it into these terms, so I would like to quote what B. Grasselli wrote in her book about dyslexia, so that we can immediately the crux of situation:

"If all this is not understood, one ends up observing dyslexia only as a problem and neglects all the potential that can be and must emerge [...]. The extraordinary aspect of dyslexia is precisely this unique mixture of talents and difficulties and if all this isn't understood and focuses attention only on the difficulties, the results that will be obtained will be those of creating continuous suffering and frustration that will push these people to make educational choices and in general low level life and that don't correspond at all to their real potential".( Grasselli, 2012).

In addition to having learning problems, people suffering from dyslexia also have problems with cognition of their bodies within the space and with musical rhythm.( Cassese, F.P., Raiola, G. 2017).

The aim of this pilot is case study . It wants to study a case of dyslexic athlete related to performance, selfesteem and sociality.(D'Isanto, T. et al., 2019).

In the previous study the athlete had difficulty in coordinating and especially in conceiving herself within the race platform, so this led her to have little self-esteem and consequently to relate little with her classmates. All this also had a great impact on her relationship with family members, teachers and anyone who tried to relate to her. 


\section{METHODS AND TOOLS}

The method used is called "case study". It is a set of ways of doing research that have in common the decision to focus the cognitive investigation on a "situation" that may be indicative of a larger set of problems. The observation was purely direct and participatory (Altavilla et al., 2018):

choose a situation that really happened;

collect most of the information on the situation identified;

the material collected is processed, it is sorted logically and sequentially;

a draft of the case is drawn up;

information that can cause confusion is eliminated;

the missing elements and information are identified for a complete understanding of the case; the case drawn up is examined by an expert who may recommend any corrections or additions; a description of the case is drawn up and any documents referred to in the description are attached; a record is prepared for the presentation of the case and for its discussion.

The case study method provides the use of a team of observers that are:

coach;

family;

two classmates.

\section{THE APPROACH}

The ethnographic approach is the method with which field research operates. It means going to those who want to study for a certain period of time, and using some research techniques (such as observation or interview) in order to collect a set of data that once interpreted, make it possible to understand the culture under consideration. (Di Tore et al., 2018 ).

It consists of a method of investigation that uses the use of participating observation as a privileged technique for the detection of information, use and consumption behaviour, in specific contexts.(Valentini, et al., 2018.).

This technique allows to reconstruct from within the symbolic world and the relational dynamics of the group, of the community, object of observation. In reality, participating observation is frequently integrated with the use of other detection techniques (e.g. non-standardised interviews, life stories) ( Altavilla, et al., 2018).

\section{RESULTS}

It was found that the gymnast manages to achieve the same results as the other gymnasts who train with her, but showing a small difficulty in teamwork. (Valentini, et al., 2018).

The gymnast finds these difficulties in teamwork because she cannot immediately learn the work to be done and therefore confuses the rest of the team (D'Elia F., 2019); but this does not mean that on an individual level, once the technical gesture has been acquired, she does the same as all the other gymnasts.( Raiola, G. 2015). 
Table 1. Individual training session

\begin{tabular}{|c|c|c|c|}
\hline \multicolumn{4}{|c|}{ INDIVIDUAL TRAINING SESSION } \\
\hline \multicolumn{4}{|c|}{ The gymnast studies rhythmic gymnastics' body difficulties (BD) and equipment difficulties (AD). } \\
\hline Type of exercise & September-December & January-March & April-July \\
\hline Jumps & $\begin{array}{l}\text { The gymnast begins to } \\
\text { approach with jumps, } \\
\text { beginning to perceive how } \\
\text { to position her body on the } \\
\text { ground. }\end{array}$ & $\begin{array}{l}\text { The gymnast starts to } \\
\text { perform the jumps, but } \\
\text { without being able to } \\
\text { coordinate her arms (she } \\
\text { will only be able to do so at } \\
\text { the end of this second } \\
\text { period). }\end{array}$ & $\begin{array}{l}\text { The gymnast has finally } \\
\text { reached the same level as } \\
\text { her team-mates have } \\
\text { reached in the previous } \\
\text { months. }\end{array}$ \\
\hline Balances & $\begin{array}{l}\text { The gymnast starts to } \\
\text { approach with balances, } \\
\text { supporting herself with } \\
\text { espaliers or elastics. }\end{array}$ & $\begin{array}{l}\text { The gymnast manages to } \\
\text { hold on very well in } \\
\text { balance, but doesn't make } \\
\text { the movement with her } \\
\text { arms at the time set to } \\
\text { ensure that the difficulty is } \\
\text { valid in the competition. }\end{array}$ & $\begin{array}{l}\text { The gymnast has finally } \\
\text { reached the same level as } \\
\text { her team-mates have } \\
\text { reached in the previous } \\
\text { months, managing to } \\
\text { maintain the balance } \\
\text { perfectly and coordinating } \\
\text { very well her arms. }\end{array}$ \\
\hline Rotations & $\begin{array}{l}\text { The gymnast begins to } \\
\text { approach with rotations, } \\
\text { positioning herself in the } \\
\text { same form as the balances } \\
\text { previously studied, turning } \\
\text { in } 4 \text { steps while remaining } \\
\text { in the same position of the } \\
\text { established balance. }\end{array}$ & $\begin{array}{l}\text { The gymnast is able to } \\
\text { carry out the rotation, but } \\
\text { she is not always able to } \\
\text { complete it at } 360^{\circ} \\
\text { because she is not always } \\
\text { able to perceive the } \\
\text { complete rotation. }\end{array}$ & $\begin{array}{l}\text { The gymnast has finally } \\
\text { reached the same level as } \\
\text { her team-mates have } \\
\text { reached in the previous } \\
\text { months, managing to } \\
\text { perceive well the space } \\
\text { around her. }\end{array}$ \\
\hline
\end{tabular}

Table 2. Group training session

GROUP TRAINING SESSION

The gymnast studies rhythmic gymnastics' body difficulties (BD) and tool difficulties (AD) with her group.

\begin{tabular}{|l|l|l|l|}
\hline Type of exercise & September-December & January-March & April-July \\
\hline \multirow{5}{*}{ Exchanges } & $\begin{array}{l}\text { The gymnast always } \\
\text { arrives late on the music } \\
\text { so she can't make the } \\
\text { exchange with the team } \\
\text { in time. }\end{array}$ & $\begin{array}{l}\text { The gymnast has understood } \\
\text { the time in which to make the } \\
\text { exchange, but cannot calculate } \\
\text { the distance at which to throw } \\
\text { the tool. }\end{array}$ & $\begin{array}{l}\text { The gymnast has a } \\
\text { complete perception of } \\
\text { herself and of the space } \\
\text { around her so she } \\
\text { succeeds in all her intents. }\end{array}$ \\
\hline Collaborations & $\begin{array}{l}\text { The gymnast always } \\
\text { arrives late on the music } \\
\text { so she can't make the } \\
\text { collaboration with the } \\
\text { team in time. }\end{array}$ & $\begin{array}{l}\text { The gymnast has understood } \\
\text { the time to do the collaboration, } \\
\text { but she doesn't always manage } \\
\text { to coordinate the tool. }\end{array}$ & $\begin{array}{l}\text { Tymnast has a } \\
\text { complete perception of } \\
\text { herself and of the space } \\
\text { around her so she } \\
\text { succeeds in all her intents. }\end{array}$ \\
\hline
\end{tabular}


Table 3. After one-year training (July 2018)

\begin{tabular}{|c|c|c|}
\hline \multicolumn{3}{|c|}{ Performance after one-year training (July 2018) } \\
\hline Typology & Correct performance & Gymnast's response \\
\hline $\begin{array}{l}\text { Coordination with } \\
\text { rope }\end{array}$ & $\begin{array}{l}\text { Warm-up and technique: } \\
\text { jumps and little jumps; } \\
\text { oscillations; } \\
\text { crossings; } \\
\text { echappé; } \\
\text { rope closed, passages under the } \\
\text { legs; } \\
\text { throws and shots. }\end{array}$ & $\begin{array}{l}\text { The gymnast performs any type of exercise } \\
\text { perfectly: both technical with the tool and physical. }\end{array}$ \\
\hline $\begin{array}{l}\text { Coordination with } \\
\text { hoop }\end{array}$ & $\begin{array}{l}\text { Technique: } \\
\text { crossings; } \\
\text { rotations; } \\
\text { rolls; } \\
\text { rotations around a part of the body } \\
\text { or around its own axis; } \\
\text { throws and shots. }\end{array}$ & $\begin{array}{l}\text { The gymnast performs any type of exercise } \\
\text { perfectly: both technical with the tool and physical. }\end{array}$ \\
\hline $\begin{array}{l}\text { Coordination with } \\
\text { ball }\end{array}$ & $\begin{array}{l}\text { Technique: } \\
\text { rolling movements; } \\
\text { eight-movements; } \\
\text { oscillations; } \\
\text { dribblings; } \\
\text { throws and shots. } \\
\end{array}$ & $\begin{array}{l}\text { The gymnast performs any type of exercise } \\
\text { perfectly: both technical with the tool and physical. }\end{array}$ \\
\hline $\begin{array}{l}\text { Coordination with } \\
\text { clubs }\end{array}$ & $\begin{array}{l}\text { Technique: } \\
\text { rounds; } \\
\text { circumcisions; } \\
\text { asymmetrical movements; } \\
\text { moulinets; } \\
\text { throws and shots. }\end{array}$ & $\begin{array}{l}\text { The gymnast performs any type of exercise } \\
\text { perfectly: both technical with the tool and physical. }\end{array}$ \\
\hline $\begin{array}{l}\text { Coordination with } \\
\text { ribbon }\end{array}$ & $\begin{array}{l}\text { Technique: } \\
\text { circumcisions; } \\
\text { spirals; } \\
\text { coils; } \\
\text { throws and shots. } \\
\end{array}$ & $\begin{array}{l}\text { The gymnast performs any type of exercise } \\
\text { perfectly: both technical with the tool and physical. }\end{array}$ \\
\hline
\end{tabular}

\section{CONCLUSIONS}

Rhythmic gymnastics is a really selective sport, but in this case the barriers that have been raised have been broken down by a lot of power and determination.(Senatore, B., D'Elia, F. 2018).

In addition to working on herself, the gymnast has found benefit by relying on a figure who believed in her and her potential and I think she believed so much in herself because to the first time she was not treated as "being different", but as an ordinary person who was in that environment to play a sport.(Mantonavi, 2014).

These results encourage to explore the links between activities and data because you have in front of you an athlete to all intents and purposes (Gaetano, 2015), with every pros and cons that every human being can 
show, even if in this case the corrections must be made in a more patient way and for the results you have to wait a little more time. (Raiola, et al., 2015).

\section{REFERENCES}

Altavilla, G. (2014). Effects of the practice of muscle stretching [Učinci vježbanja stretchinga muskulature] Sport Science, 7 (1), 66-67.

Altavilla, G., D'Isanto, T., Di Tore, A.P., Raiola, G. (2018). Free throw and outcomes: Pilot study on intensive training versus extensive one, Journal of Human Sport and Exercise, 13 (3), 494-503. https://doi.org/10.14198/ihse.2018.133.02

Altavilla, G., D'Elia, F., Raiola, G. (2018). A brief review of the effects of physical activity in subjects with cardiovascular disease: An interpretative key, Sport Mont, 16 (3), 103-106. https://doi.org/10.26773/smj.181018

Altavilla, G., Di Tore, P.A. (2016). Physical education during the first school cycle: A brief social performance aspects that differentiate male athletes from females and practical consequences, Journal of Physical Education and Sport, 17, 2183-2187.

Altavilla, G., Di Tore, P.A., Riela, L., D'Isanto, T. (2017). Anthropometric, physiological and psychopedagogical summary. Journal of Physical Education and Sport, 16 (2), 340-344.

Altavilla, G., Furino, F., Marika, D.P., Raiola, G. (2015)Physical skills, sport learning and socio-affective education [Fizičke vještine, sportsko učenje I društveno-afektivno obrazovanje].

Altavilla, G., Gaetano, R. (2018). Physiological effects of warm-up and problems related to team sports, Sport Science, 11, 83-88.

Cassese, F.P., Raiola, G. (2017). The importance of sport in disability management [Važnost sporta u upravljanju kod invaliditeta] Sport Science, 10, 7-11.

D'Isanto, T. (2016). Pedagogical value of the body and physical activity in childhood [Pedagoška vrijednost tijela i tjelesne aktivnosti u djetinjstvu], Sport Science, 9, 13-18.

D'Isanto, T., D'Elia, F., Raiola, G., \& Altavilla, G. (2019). Assessment of sport performance: theoretical aspects and practical indications. Sport Mont, 17(1), 79-82. https://doi.org/10.26773/smj.190214

D'Isanto, T., Di Tore, P.A. (2016). Physical activity and social inclusion at school: A paradigm change. Journal of Physical Education and Sport, 16, pp. 1099-1102.

D‘Elia, F. (2019). The training of physical education teacher in primary school. Journal of Human Sport and Exercise, 14(1 proc), S100-S104. https://doi.org/10.14198/jhse.2019.14.Proc1.12

Di Tore, A.P., Raiola, G., D'Isanto, T. (2018). Situation awareness in sports science: Beyond the cognitive paradigm [Situacijska svijest u sportskoj nauci: Van kognitivne paradigme], Sport Science, 11 (1), 44-48.

Di Tore, P.A., Raiola, G. (2012). Case study on physical education and sport in Naples, Italy, Mediterranean Journal of Social Sciences, 3 (11), 471-476.

Di Tore, P.A., Raiola, G. (2012). Exergame-design and motor activities teaching: An overview of scientific paradigms on motor control, Mediterranean Journal of Social Sciences, 3 (11), 119-122.

Di Tore, P.A., Raiola, G. (2012). Exergames in motor skill learning, Journal of Physical Education and Sport, 12 (3), 358-361.

Di Tore, P.A., Raiola, G., Altavilla, G., Barba, S., Pignato, S., Lipoma, M. (2016). Motor imagery, perspective taking and gender differences: A VVIQ2-based study. Journal of Human Sport and Exercise, 11 228-232. https://doi.org/10.14198/jhse.2016.11.Proc1.13

Di Tore, P.A., Raiola, G., Altavilla, G., Gervilli, M.G., Pignato, S., Lipoma, M. (2016). Visual motor skills and reading fluency: A correlational study. Journal of Human Sport and Exercise, 11(Proc1): S233S238. https://doi.org/10.14198//hse.2016.11.Proc1.14 
Di Tore, P.A., Schiavo, R., D'Isanto, T. (2016). Physical education, motor control and motor learning: Theoretical paradigms and teaching practices from kindergarten to high school, Journal of Physical Education and Sport, 16 (4), 1293-1297.

Federazione Ginnastica D'ttalia-Procedure Federali e Norme Tecniche. http://www.federginnastica.it/documenti-federali/category/171-procedure-federali-e-normetecniche-2018.html

Gaetano, R., Paloma, F.G., Gaetano, A. (2015). Anxiety in the youth physical and sport activity, Mediterranean Journal of Social Sciences, 6 (3), pp. 227-230. https://doi.org/10.5901/miss.2015.v6n3s2p227

Insegnare per allenare. Claudio Mantovani, SDS Edizioni, 2014.

La dislessia: Interventi della scuola e della famiglia. Chiara De Grandis, Erickson, 2007.

Leggere la dislessia. Resilienza, riconoscimento, competenze. Bruna Grasselli, Armando Editore, 2012.

Raiola, G., Altavilla, G., Filippo, G.P. (2015). Effects of physical activity and sports in the reduction of stereotypy in blind subjects [Učinci tjelesne aktivnosti i sporta u smanjenju stereotipa kod slijepih subjekata] Sport Science, 8, pp. 52-55.

Raiola, G. (2015). Sport skills and mental health, Journal of Human Sport and Exercise, 10 369-376. https://doi.org/10.14198/ihse.2015.10.Proc1.27

Rago, V., Pizzuto, F., Raiola, G. (2017). Relationship between intermittent endurance capacity and match performance according to the playing position in sub-19 professional male football players: Preliminary results. Journal of Physical Education and Sport, 17 (2), 688-691.

Raiola, G. (2012). Bodily communication in volleyball between human and experimental sciences, Mediterranean Journal of Social Sciences, 3 (1), 587-597.

Raiola, G. (2013). Body knowledge and motor skills, Knowledge Cultures, 1 (6), 64-72.

Raiola, G. (2014). Motor control and learning skills according to cognitive and ecological dynamic approach in a vision on behaviorism, cognitive, Gestalt and phenomenology theories, Mediterranean Journal of Social Sciences, 5 (15), 504-506. https://doi.org/10.5901/miss.2014.v5n15p504

Raiola, G. (2014). Teaching method in young female team of volleyball, Journal of Physical Education and Sport, 14 (1), 74-78.

Raiola, G. (2017). Motor learning and teaching method, Journal of Physical Education and Sport, 17, 2239-2243.

Raiola, G., Scassillo, I., Parisi, F., Di Tore, P.A. (2013). Motor imagery as a tool to enhance the didactics in physical education and artistic gymnastic. Journal of Human Sport and Exercise, 8 (2 PROC), pp. 93-97. https://doi.org/10.4100/jhse.2012.8.Proc2.11

Raiola, G., D'Elia, F., \& Altavilla, G. (2018). Physical activity and sports sciences between European research council and academic disciplines in Italy. Journal of Human Sport and Exercise, 13(2proc), S283-S295. https://doi.org/10.14198/ihse.2018.13.Proc2.13

Raiola, G., Di Tore, A. (2012). Non-verbal communication and volleyball: A new way to approach the phenomenon, Mediterranean Journal of Social Sciences, 3 (2), 347-356. https://doi.org/10.5901/miss.2012.v3n2.347

Raiola, G., Di Tore, P.A. (2012). Bodily communication skills and its incidence on female volleyball championship to enhance didactics, Journal of Human Sport and Exercise, 7 (2), 365-375. https://doi.org/10.4100/jhse.2012.72.03

Raiola, G., Di Tore, P.A. (2012). Statistical study on bodily communication skills in volleyball to improve teaching methods, Journal of Human Sport and Exercise, 7 (2), 468-488. https://doi.org/10.4100/jhse.2012.72.12 
Raiola, G., Di Tore, P.A. (2017). Motor learning in sports science: Different theoretical frameworks for different teaching methods [Motoričko učenje u sportskoj znanosti: Različiti teorijski okviri za različite metode poučavanja] Sport Science, 10, 50-56.

Raiola, G. (2015). Inclusion in sport dance and self perception, Sport Science, 8, pp. 99-102.

Senatore, B., D'Elia, F. (2018). Rhythmic gymnastics and Dyslexia: a premilinary case study. Journal of Physical Education and Sport, 18, 2101-2105.

Valentini, M., Bernardini, C., Beretta, A., Raiola, G. (2018). Movement and language development as an early childhood twin strategy: A systematic review, Sport Mont, 16 (3), 107-112. https://doi.org/10.26773/smi.181019

Valentini, M., Riccardi, F., Raiola, G., Federici, A. (2018). Educational research: Motor area and relational area during children's personality development, Journal of Physical Education and Sport, 18, 2157 2174.

\section{@ $\Theta \Theta$}

This work is licensed under a Attribution-NonCommercial-NoDerivatives 4.0 International (CC BY-NC-ND 4.0). 